\title{
LXXXVII. Account of a volcanic eruption in Iceland
}

\section{Dr. Forchhammer}

To cite this article: Dr. Forchhammer (1822) LXXXVII. Account of a volcanic eruption in Iceland, Philosophical Magazine Series 1, 59:290, 428-432, DOI: 10.1080/14786442208652768

To link to this article: http://dx.doi.org/10.1080/14786442208652768

曲 Published online: 29 Jul 2009.

Submit your article to this journal $\pi$

LII Article views: 4

Q View related articles $₫$ 
to put the cost at the highest point, more strongly to enforce the advantage resulting from the practice, as it thus leaves nothing to object to.

This field had in the last course 30 tons of manure; it is strong clay. First crop, potatoes, product 26 hundred stone per acre: sown with wheat and clover; both these crops were admirable. The oats this last year are calculated to produce 60 Winchester bushels per acre; it is now preparing for green crop again, and to have 50 tons of manure per acre. Admitting the green crop to profit three pounds per acre by the drainage, which is only half what was lost at average prices this year on the Swede crop, this on the 50 acres would be one hundred and fifty pounds : calculating it to yield three Winchester bushels per acre more of wheat, at $7 s$. per bushel, this would be fifty-two pounds ten shillings and ten-pence per acre; for the clover for two years $50 l$. more, making a probable increase of produce, without any extra expense, of $252 l$. 10s. Thus, in a five years course the whole expense will, in all probability, be repaid, and an annual permanent increase of rent to the amount of 60 per cent. gained.

Wet is more destructive to pasture than it is to grain and green crops ; and as pasture is the most material object near to towns, draining, in such situations, is a more profitable improvement than in any other situation, and will consequently justify a greater expense.

When once dry land is well laid down to pasture, the improvement is permanent. If tlooded with water, it cannot remain for any length of time in pasture, but must be again brought under tillage. On wet soils, improvement is almost labour in vaincostly at all times, but now ruinous.

Should the Society deem this undertaking as meriting their attention, it will be highly gratifying to me, who owe them many and great obligations.

The ambition of meriting the honour of their rewards, first directed my attention to agriculture, and I trust the result has not altogether been without its advantages to the public.

$$
\text { I am, sir, \&c. \&c. }
$$

John Christian Curwen.

LXXXVII. Account of a Volcanic Eruption in Iceland. By Dr. ForchHammer*.

$\mathrm{T}_{\mathrm{HE}} \mathrm{v}$ very low state of the barometer throughout a great part of Europe in the months of December and January, althougin not

* From Annals of Plijlosophy, No. Is. 
immediately followed by any eruption of the volcanoes in Italy, excited apprehensions of violent volcanic phænomena in Iceland; and in the month of March, letters were received in Copenhagen from which the following account is drawn up.

In the beginning of the month of September, the frost began on the east coast, and on the east part of the north const of Iceland, with a violence that was quite unexpected after the experience of the preceding years. An anazing quantity of snow fell, and the Greenland ice surrounded the whole east and north coast, accompanied as usual by continual snow and frost. It was remarkable that the fine weather continued on the south coast of the island till the beginning of November, the lowest state of the thermometer at Nress, near Reikiavig, being on the $23 \mathrm{~d}$ and 24 th of September $=41^{\circ}$ Fahr. On the 19th of October it suddenly fell to $23^{\circ} \mathrm{Fahr}$., which Jasted, however, only for one day, and before and after that time the temperature of the atmosphere was constantly above the freezing point, until on the first of November, when constant frost began.

The island, though frequently alarmed by earthquakes, had experienced no volcanic eruption since that famous one of 1783 and 1784 fiom the Skaptaa-Jokkul, which destroyed such a great part of the cultivated lands, except some small eruptions which were said to have taken place in the interior, far from the inhabited part of the island, and which passed away without attracting further notice, when in December 1821, a new crater was suddenly formed on the Eyafjeld-Jokkul, a mountain of which, among the numerous volcanic eruptions, only a single one is mentioned, in the year 1612, when a great part of the ice of the mountain burst, and was thrown into the sea.

The Eyafjeld-Jokkul (known among sailors under the name of Cape Hekla) is the highest of all the mountains in Iceland; and, according to the last measurements, is 5666 feet high. It is the southernmost of the chain of mountains in which the dreadful eruptions in the middle of the last century took place, and at about equal distances from the Kolla and Hekla. From 1024 to 1766 , twenty-four eruptions are recorded to have occurred. That part of the mountain where the crater was formed borders two sides the cultivated land, which belongs to the hundred (Syssel) of Rangarvalla, in the south part of the island.

The following account is an extract of a letter from M. Bryniulo Sivertsen, Minister at Holt, in Eiafields-boigden, to the Bishop of Iceland, M. Vidalin :- " The real crater is about five miles from my house at Holt. The fire made its way suddenly by throwing off the thick mass of ice which scarcely ever melts, and of which, one mass, 18 feet high, and 20 fathoms in circum- 
ference, fell towards the north, and, therefore, fortunately not over the village. $\Lambda$ the same time, a number of stones of different sizes slipped down the mountain, accompanied by a noise like thunder; no real earthquake, however, was folt. After this, a prodigiously high column of flame rose from the crater, which illumined the whole country round so completely, that the people in the house at Holt could see as perfectly at night as in the day time. At the same time much ashes, stones, gravel, and large half-melted pieces of the rock, were thrown about, some of which amounted to the weight of 50 pounds. In the following days, and until the new year commenced, a great quantity of fine powder of pumice fell in the surrounding country according to the direction of the wind, so that a thick bed of it covered the fields. It resembled the falling of snow, and penetrated through all openings into the houses, where it exhaled an unpleasant smell of sulphur. The eyes suffered extremely by this dust. At Christmas, a violent storm from the south raged; it rained hard, which produced the good effect of blowing and washing away the ashes from the fields, so that they will do but little harm. We think ourselves extremely fortunate that so frightful a revolution in our immediate neighbourhood has produced no bad effects either on men or animals."

Another extract of a letter from M.'Terve Johansen, the Provost at Breidebolstad, about $18 \frac{\mathrm{I}}{2}$ miles to the west of the volcanoes, dated the first of February 1822, gives the following additions: "We still see the column of fire of the volcano shining with the same clearness as in the beginning, without, however, throwing lava into the inbabited part of the island. The ashes are greyish-white, have a sulphurous taste, and it is reported that they burn with flame when thrown into the fire. The ice of the Jokktil was twice broken, and an eye-witness has assured me that some of the pieces were three times as high as himself, and of many fathoms in circumference. Among the numerous balf-melted stones, one has been found thrown to the distance of about five miles from the crater. We have had no accounts of the bad cffects of this eruption either on men or animals. The thick mass of ashes spread over the land of Vester Eyafield and Oster Landoe, which began to occasion diseases among the sheep, has been blown away by a heavy storm, and since that time the wind has carried the ashes from the volcano into the uninhabited mountains; the diseases among the sheep soon disappeared."

The third account is from M. Steingrim Johnson, Provost at Rangarvalla and Vestmamoesyssel, and written from Orlde, abont 30 to 35 miles to the $W$. of the volcano, dated December 19, 1821 . 
" On Wednesday, December 19, at twilight, and later in the evening, a reddish light appeared on the $\mathrm{E}$., which was the more surprising, as it was clear.

Dec. 20.-At one o'clock in the afternoon, a number of rather shining clouds was seen collected about the top of the mountain above Eyafjeld-Jokkul, E.S.E. from Odde; the clouds scon changed into a high column of smoke increasing in thickness and darkness. Though the weather was clear and calm, the smoke was carried to the soith; at sunset, the eruption seened to cense, but the smoke soon rose again, and even more violentily than before. When it was dark, we clearly satw the moving and the sparkling flame ; from which we concluded that the cruption must be violent. Afterwarls we heard that it was on the east or south side of the Vesterjokkut, near Hulnasten, and opposite to the farm-house of skaale, in the parish of Holt.

Dec. 21.-There was a violent storm, and the fire was observed varying in intensity; clouds of smoke rose with great violence. They remained on the mountain, and to the west of the Jokkul, whose white brilliant colour was now destroyed by the shower of ashes.

Dec. 22.-The same phrmomena; the clouds increased, and spread all over the sky, primcipally towards the south.

Dec. 23.-The same smoke. In Hvols-Reppen, and in this parish, the people believed that they saw the falling of ashes which came from the north-east. Afterwards we were told that a great quantity of them had fallen that night, and before, in the villages that were nearest to the volcano.

Dec. 24, 25.-The clouds of smoke remained on the same place, and in the same direction, as before; now and then the fire was observed on the place of the first eruption.

Dec. 26, 27.- Heavy storm from north-east; the clouds of smoke on the same place.

Dec. 28.-The weather began to get more calm; it seemed as if the column of clonds was divided into two, which took different directions by different currents of wind.

Dec. 29. - Weather calm and pleasant. The clouds of smoke moved towards the north and east over the ice mountains. Late in the evening a mild rain.

During this whole time, the cold was moderate, not exceeding $25^{\circ}$ Fahrenheit, and sometimes it was $4^{\circ}$ above the freezing point. It is reported that the water of the river which falls into the - and in the other rivers that come from the Jokkul and the surrounding mountains, had increased considerably during the first days of the eruption. In the vicinity of the volcano a constant rumbling noise was heard, now and then accom- 
panied by a dreadful crash, as if the whole immense masses of stone and ice were going to fall together. The greater part of the ashes was fortunately carried towards the north, into uninhabited mountains and heaths, where also a great quantity of pumice has fallen."

In another letter from the same Provost, dated Feb. 23, it is said, "The clouds of smoke have not yet disappeared, and torlay they are increased. No ashes, however, have been observed during a long time, and the Jokkul has resumed its'shining white colour, so that the rain and wind must have removed the ashes. The smoke greatly resembles the steam rising from boiling water, and certainly owes its origin to the fire below. Some imagine they have observed that the Jokkul has decreased, and is now lower near the crater, which certainly must now be larger than before, the column of clouds increasing in circumference. So it appears at least from this side from N. to $S$.; but whether the same has taken place in the other direction, from E. to W., I am not able to say. It has been reported that to the $E$. two other volcanoes have had eruptions, the mountains Katla and Oraefa Jokkul, but nothing is known about it. Since the eruption, the weather has become worse, owing to its unparalleled variableness, storms, and afterwards cold, and a great quantity of snow."

Dr. Thorsteinson, in a letter to Prof. Oersted, gives the following additions:- "Since the first of January, the violence of the eruption has been decreasing. Though the town of Reikiavig is about 74 miles from the volcano, the flame was observed there several times at night, when the weather was clear. People that recollect the eruptions of 1766 and 1783 think this trifling, but principally because it has done no harm. Though distant about 74 miles from the volcano, I thought that the weather became much milder after the eruption. Though the barometer was pretty low during the eruption, yet it was lowest on Feb. 8 , when it was only $27 \cdot 25$ inches; but the fire did not increase, nor did we feel any thing like an earthquake; but near the volcano, they had constantly small shocks."

The vessel which brought this news had left Iceland on the 7 th of March, and it is reported that the sailors when at sea again saw a violent fire. 